\title{
Possible Hepatoprotective Effects of Mustard Seed Extract Against Paracetamol-Induced Liver Injury in Male Albino Rat
}

\author{
Howayda El Sayed Khaled* \\ Zoology Department, Faculty of Science, Suez University, Suez, Egypt
}

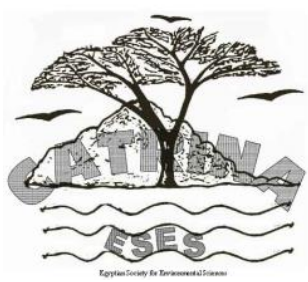

\begin{abstract}
The evaluation of hepatoprotective effect of Mustard seed (MS) extract was assessed against paracetamol induced hepatic injury in albino rats. Animals were divided into 4 groups, each of 5 rats. Group I served as control group; group II treated with ethanolic extract from Mustard seed at a dose level of $500 \mathrm{mg} / \mathrm{kg}$ body weight orally once for 10 days. Group III represents induced liver injury animals using single dose of paracetamol (PCT). Group IV combined treatment of MS extract and PCT. Elevated serum marker enzymes such as ALT, AST, ALP, GGT and LDH were observed due to paracetamol treatment. Combined administration of MS extract with PCT to rat partially normalized the altered hepatic biochemical markers caused by PCT. Moreover, PCT caused histological changes in livers of rat including swelling and dilation in sinusoidal space, inflammation in portal tract and hepatocytes, as well as, hyperplasia in Kuppfer cells. However, co-administration of MS extract with PCT alleviated to some extent the changes caused by PCT but not as the normal liver. The results of this study strongly indicate that Mustard seed has possible potent hepatoprotective action against paracetamol induced hepatic damage in rats.
\end{abstract}

Keywords : liver injury, paracetamol, mustard seed.

\section{INTRODUCTION}

The liver has a vital significance in metabolism as well detoxification and removal of toxic substances. It is frequently affected by a multitude of chemicals and drugs, which can harm and weaken it, eventually leading to diseases like hepatitis or cirrhosis (Zimmerman et al., 1994; Nassini et al., 2010). Paracetamol's hepatotoxicity is triggered by its reactive metabolite $\mathrm{N}$-acetylp-benzoquinone imine (NAPQI), which causes oxidative stress and glutathione (GSH) depletion. Paracetamol toxicity is due to the construction of toxic metabolites when a part of it is metabolized by cytochrome P450 (Walubo et al., 2004). In view of unwanted side effects of synthetic agents, there is growing interest in estimating traditional herbal medicines that are demanded to have hepatoprotective activity (Anantha et al., 2012).

There has been a revival of attention in plant-based medicines due to the increase responsiveness of the limited ability of synthetic pharmaceutical product to control major disease and the need to determine new molecular structures as the lead compounds from other sources, comprising the plant kingdom (Hussain et al., 2011). Mustard seed is a well-known medicinal plant in traditional medicinal system and new scientific studies have highlighted the possible use of mustard seed modern medicine (Lai, p. and Roy, 2004). The present work aims to observe the effect of mustard seed extract for protection of prompted liver injury in male rat; using the histological and biochemical changes as an indicator.

\section{MATERIALS AND METHODS}

\section{Animals}

Twenty male albino rats weighing $120-135 \mathrm{~g}$ were obtained from the Animal House of Faculty of veterinary
(Ismaillia, Egypt). The animals were fed a standard diet (El-Nasr Company, Abou-Zaabal, Cairo, Egypt) and allowed free access to water. The rats were kept under standard conditions of temperature $\left(22 \pm 1.1^{\circ} \mathrm{C}\right)$ with 12 h light/12-h dark cycle.

\section{Drugs and chemicals}

Paracetamol was provided from El-Nile Pharmaceutical Company (Cairo, Egypt). All the reagents used were of analytical grade. The dried mustard seeds were purchased from local market, identified and authenticated by botanists in the department of Botany, Faculty of Science, Suez University, Egypt.

\section{Preparation of seed extracts}

The seeds were grounded to a fine powder using a clean mortar and pestle, their powder was stored in a clean bottle at room temperature in dark place. The powdered seed samples $(100 \mathrm{~g})$ were weighed by using a sensitive balance and extracted with $300 \mathrm{ml}$ of $70 \%$ ethanol. Then shacked for about 3days. The extracts were filtered through Whatman No. 1 filter paper followed by evaporation of alcohol. The extract were transferred to glass vials which stored at $4^{\circ} \mathrm{C}$ until useing (Amarowicz et al., 1996)

\section{Experimental design}

Animals were divided into 4 groups, each of 5 rats. Group I: The rats were injected orally with $(1 \mathrm{ml} / 100$ g.bw) saline once daily for 10 days. Group II: The rats were injected orally with Mustard seed extract in a dose of $500 \mathrm{mg} / \mathrm{kg}$ bw once daily for 10 consecutive days (Muriel et al., 1992). Group III: The rats were injected orally with Paracetamol in a single dose of $300 \mathrm{mg} / \mathrm{kg}$ at the fourth day of experiment (Mcgill et al., 2012). Group IV: The rats were injected orally with mustard $(500 \mathrm{mg} / \mathrm{kg}$ ) for 10 consecutive days. A single dose of PCT $(500 \mathrm{mg} / \mathrm{kg})$ was administrated orally at the fourth 
day of experiment .On the tenth day, rats were anaesthetized with ether and

\section{Serum preparation}

At the end of the experiment, rats were anaesthetized with light diethyl-ether. The blood samples were obtainned directly from the ventricle of the heart and transferred immediately into centrifuge tubes for the separation of serum. The collected blood, were allowed to stand in slanting position for about 45 minutes at $4^{\circ} \mathrm{C}$. The serum was separated by centrifugation at $2500 \mathrm{rpm}$ for $10 \mathrm{~min}$. The obtained serum was used to estimate the intended biochemical parameters.

\section{Determination of liver function}

\section{A. Alanine Aminotransferase (ALT)}

ALT was measured using commercially available kit provided by SPINREACT, S.A. Ctra. Santa Coloma, Spain. Alanine aminotransferase (ALT) catalyses an amino group from alanine to $\alpha$-ketoglutarate forming piruvate and glutamate. The pyruvate produced is converted to lactate by lactate dehydrogenase (LDH) and NADH. The rate of reduction in concentration of NADH, measured photometrically, is proportional to the catalytic of ALT present in the sample (Reitman and Frankel, 1957).

\section{B. Aspartate Aminotransferase (AST)}

AST was measured using commercially available kit provided by SPINREACT, S.A. Ctra. Santa Coloma, Spain. Aspartate aminotransferase catalyses the formation oxalacetate and glutamate from $\alpha$-ketoglutarate. The oxalacetate produced is converted to malate by malate dehydrogenase (MDH) and NADH. The rate of reduction in concentration of $\mathrm{NADH}$, measured photometrically, is proportional to the catalytic of AST present in the sample (Reitman and Frankel, 1957).

\section{Alkaline phosphatase}

Alkaline phosphatase activity was estimated by the method of AACC using Point Scientific, INC kit (Tietiz et al., 1986).

\section{Gamma glutamyltransferase}

Gamma glutamyltransferase $(\gamma-\mathrm{GT})$ was measured using commercial kit (Vitro Scient, Egypt) according to the method of Szasz (1969).

\section{E. Lactate dehydrogenase}

Determination of the total activity of Lactate dehydrogenase $(\mathrm{LDH})$ was by the method of Moss et al. (1987).

\section{Histopathology}

Liver tissues were cut into small pieces and fixed in $10 \%$ neutral formalin for 24 hours, and were imbedded in paraffin. Cut into five-micron-thick sections using microtom and routinely stained with eosin and counter stain hematoxyline (Junqueira et al., 1995).

\section{Statistical analyses}

The results were analyzed using SPSS 20.0 version. oneway ANOVA was used to analyze the present data, $\mathrm{p}<0.05$ was considered as statistically significant.

\section{RESULTS}

Figures (1-5) shows the effects of PCT, mustard seed extract and their combination on the indices of serum liver functions, ALT (Fig. 1), AST (Fig. 2), ALP (Fig. 3), GGT (Fig. 4) and LDH (Fig. 5). PCT resulted in a significant increase $(\mathrm{P}<0.05)$ in serum ALT, AST, ALP, GGT and LDH, as compared to the control group. Mustard seed extract administration alone for 10 days showed non-significant change compared to the negative control groups. Meanwhile, administration of mustard seed extract in combination with PCT resulted in marked reversal of induced increase in serum ALT, AST, ALP and GGT as well as LDH, as compared with induced liver injury group.

The results obtained from histological sections of livers with hematoxaline and Eosin staining for control and Mustard-treated rats were similar. Liver histologic observations of the control and Mustard-treated rats showed radially arranged hepatic cords around the central vein (Figures 1 and 2). The classic lobule was hexagonal in shape. The livers of the PCT-treated animals showed connective tissue deposition near portal triad resulting in destruction of the Iobular architecture (Fig. 4 ), congestion of central vein and centrolobular hepatocyte swelling (Fig. 4). Section of liver tissue from PCTtreated animals treated with MS-extract showed only mild dilation sinusoids between hepatocyts (Fig. 5) diminished fibrosis, congestion, incidence of inflamematory cells infiltration, centrolobular hepatocyte swellling, as compared with PCT-group.

\section{DISCUSSION}

Hepatocytes are the main component that regulates various metabolic activities of liver. Distortion of this organ will result in disorder of body metabolism (Shaker et al., 2010). This study was designed to investigate the ability of mustard seed extract to protect the liver against the oxidative stress and hepatocellular injury that follows a supratherapeutic dose of paracetamol. In agreement with previous studies (Larson et al., 2005; More et al., 2008; Chun et al., 2009), paracetamol administered to rats intraperitoneally at an over dose caused hepatic injury, as evidenced by significant elevation on the serum enzymes levels, namely AST, ALT, ALP, GGT and LDH indicating chemical induced hepatocellular toxicity. It was suggested that the hepatotoxicity of paracetamol was due to formation of a toxic metabolite, N-acetyl-p-benzoquinoeimine (NAP$\mathrm{QI})$ by cytochrome $\mathrm{P} 450$, which induced a dose dependent depletion of intracellular reduced GSH (Parmar et al., 2010; Nimila et al., 2017). Another hypothesis proposed as the mechanism of paracetamol hepatotoxicity is oxidative stress. Lipid peroxidation has been suggested to be closely related to PCT-induced toxicity (Reid et al., 2005). 
Khaled, H.E

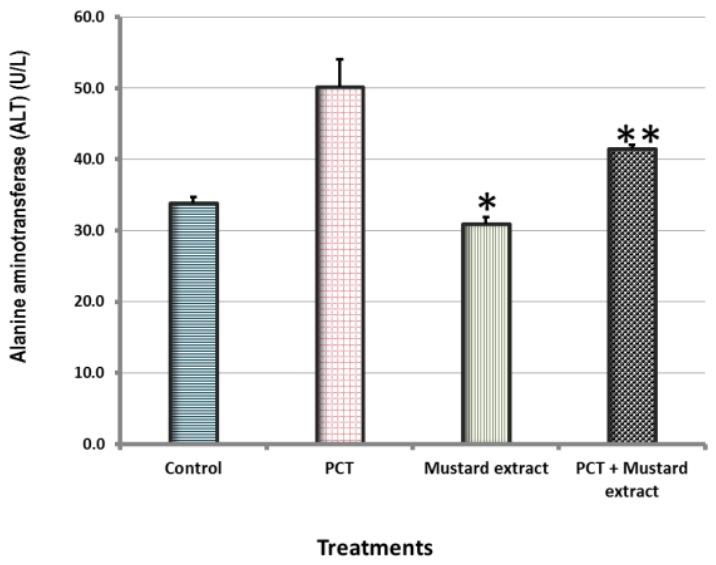

Figure (1): Histogram represents effects of Mustard seed extract daily intake for 10 days, on serum liver function indices, alanine transaminase (ALT) activity in male rats with PCT induced liver injury. Data represents the mean value \pm SE. from 5 rats / group. (*) denotes value significantly different from control group using one way ANOVA followed by Duncan $(\mathrm{p}<0.05)$. (**) represents a significant difference between experimental groups compared with PCT group using one way ANOVA followed by Duncan. $(\mathrm{p}<0.05)$.

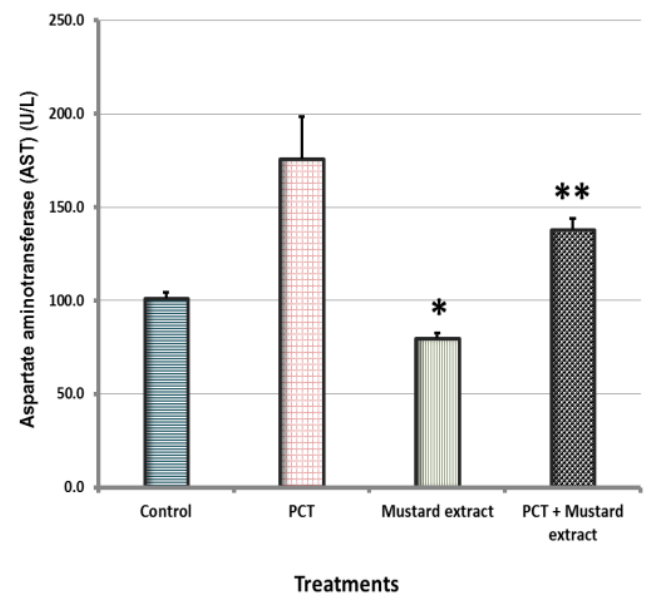

Figure (2): Histogram represents effects of Mustard seed extract daily intake for 10 days, on serum liver function indices, aspartate transaminase (AST) activity in male rats with PCT induced liver injury. Data represents the mean value \pm SE. from 5 rats / group. (*) denotes value significantly different from control group using one way ANOVA followed by Duncan $(\mathrm{p}<0.05)$. (**) represents a significant difference between experimental groups compared with PCT group using one way ANOVA followed by Duncan. $(\mathrm{p}<0.05)$.

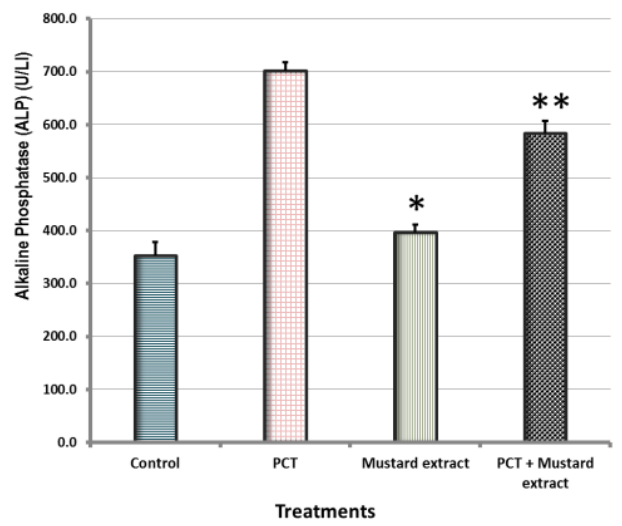

Figure (3): Histogram represents effects of Mustard seed extract daily intake for 10 days, on serum liver function indices, Alkaline phosphatase (ALP) activity in male rats with PCT induced liver injury. Data represents the mean value \pm S.E. from 5 rats / group. (*) denotes value significantly different from control group using one way ANOVA followed by Duncan $(\mathrm{p}<0.05)$. (**) represents a significant difference between experimental groups compared with PCT group using one way ANOVA followed by Duncan. $(\mathrm{p}<0.05)$. 


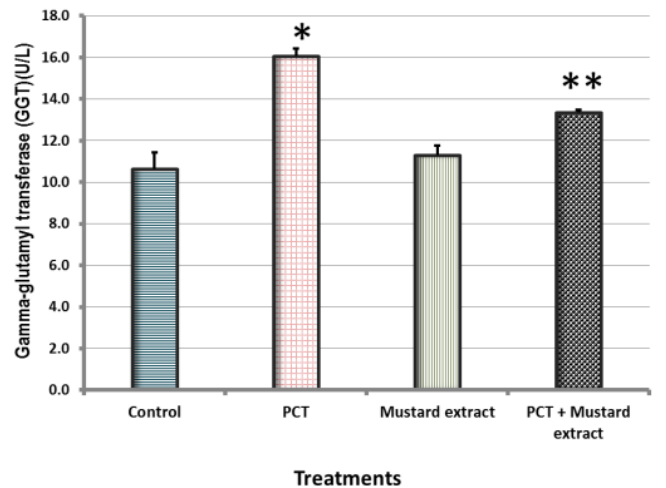

Figure (4): Histogram represents effects of Mustard seed extract daily intake for 10 days, on serum liver function indices, gamma glutamyl transferase (GGT) activity in male rats with PCT induced liver injury. Data represents the mean value \pm SE. from 5 rats / group. $(*)$ denotes value significantly different from control group using one way ANOVA followed by Duncan $(\mathrm{p}<0.05)$. $(* *)$ represents a significant difference between experimental groups compared with PCT group using one way ANOVA followed by Duncan. $(\mathrm{p}<0.05)$.

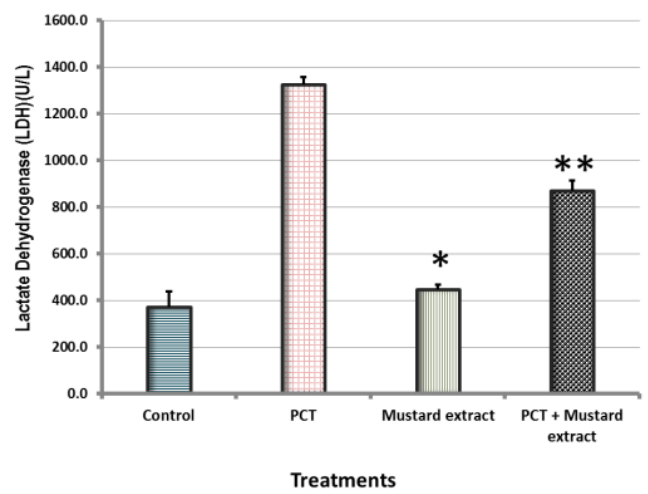

Figure (5): Histogram represents effects of Mustard seed extract daily intake for 10 days, on serum liver function indices, lactate dehydrogenase (LDH) activity in male rats with PCT induced liver injury. Data represents the mean value \pm S.E. from 5 rats / group. (*) denotes value significantly different from control group using one way ANOVA followed by Duncan ( $\mathrm{p}<0.05)$. (**) represents a significant difference between experimental groups compared with PCT group using one way ANOVA followed by Duncan. $(\mathrm{p}<0.05)$

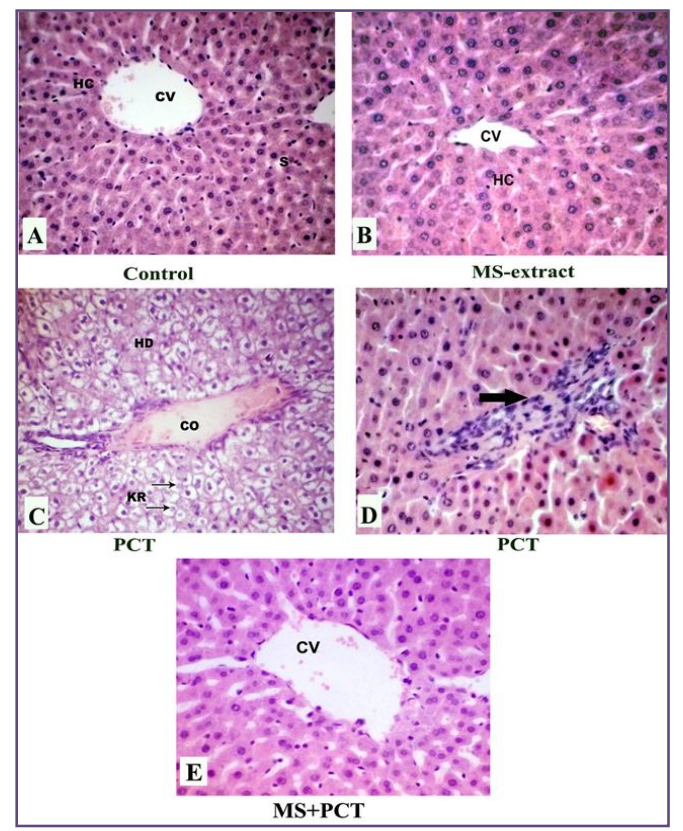

Figure (6): Representative images of liver in (A) control, Mustard-treated (B) PCT-induced liver injury group (C and D), PCTgroup treated with $500 \mathrm{mg} / \mathrm{kg}$ /day Mustard seed extract (E), In PCT-rats, hydropic degeneration (HD) of hepatocytes around the central vein, Congestion in central vein (CO) were observed. Besides connective tissue deposition near portal triad (arrow). Absence of fibrotic area could be seen following treatment with $500 \mathrm{mg} / \mathrm{kg} /$ day Mustard seed extract. (Magnification X200) 
Regarding histopathological investigation the results of the present study support the findings of the previous studies as in paracetamol treated animals, where the liver showed several alterations including cloudy swelling, infiltration of lymphocytes, sever congestion, necrotic foci and hydropic changes. The degenerated cell has karyolysed nuclei, where others showed pyknosis in which nucleus shrinked. In addition, the hepatic portal vien were congested. The histological changes induced by PCT treatment were confirmed biochemically. ALT is a cytosolic enzyme of the hepatocyte and an increase in its activity in serum reflects a leakage in plasma membrane permeability, which in turn, is associated with cell death. ALT is considered to be one of the best indicators of liver necrosis (Rosen and Keeffe, 2000). ALT and AST are the major critical enzymes in the biological processes. They are involved in the breakdown of amino acids into a-ketoacid, which is routed for complete metabolism through the Krebs cycle and electron transport chain (Maiti et al., 2004).

Treatment of rats with Mustard extracts largely prevented paracetamol induced histopathological alterations in the liver as indicated by a reduction in inflammatory cellular infiltration and hepatocytic damages when compared to paracetamol treated group. Mustard was able to attenuate the degeneration action of PTC on the liver tissue. These results strongly supports that Mustard have powerful antioxidant and hepatoprotective properties against PCT induced free radicals damage in the liver. The free radicals scavenging effects of these spices could be attributed to its higher polyphenols and flavones contents. Polyphenols are the most significant compounds for the antioxidant properties of plant raw materials (Rice-Evans et al., 1997). The antioxidant activity of polyphenols is mainly due to their redox properties, which allow them to act as reducing agents, hydrogen donors, singlet oxygen quenchers, metal chelators (Carocho and Ferreira, 2013). The presence of these antioxidant compounds mustard seed extract could have been the cause for the observed protection of liver from paracetamol induced oxidative damage.

Thus, in conclusion, the present study confirmed that mustard has a powerful antioxidant effects against paracetamol induced hepatotoxicity. Pretreatment with these spices to paracetamol injected rats was able to reduce histopathological changes happened in hepatic tissue. Further studies should be carried out to look into the different antioxidant constituents from these spices that have potent protective effect against induced hepatotoxicity.

\section{REFERENCES}

AMAROWICZ, R., U. N. WANASUNDARA, M. KARAMAĆ, AND F. SHAHIDI. 1996. Antioxidant activity of ethanolic extract of mustard seed. Molecular Nutrition and Food Research, 40(5), 261-263

ANANTHA, K.C.D., R.C. SIVA, AND R.A. MANOHAR. 2012. Hepatoprotective effect of biherbal ethanolic extract against paracetamolinduced hepatic damage in albino rats. Journal of Ayurveda and Integrative medicine, 3(4), 198.
CAROCHO, M., AND I.C. FERREIRA. 2013. A review on antioxidants, prooxidants and related controversy: natural and synthetic compounds, screening and analysis methodologies and future perspectives. Food and Chemical Toxicology, 51: 15-25.

CHUN, L.J., M.J. TONG, R.W. BUSUTTIL, AND J. R. HIATT. 2009. Acetaminophen hepatotoxicity and acute liver failure. Journal of clinical gastroenterology, 43(4): 342-349.

HUSSAIN, M. A., M.Q. KHAN, N. HUSSAIN, AND T. HABIB. 2011. Antibacterial and antifungal potential of leaves and twigs of Viscum album L. Journal of Medicinal Plants Research, 5(23): 55455549.

JUNQUEIRA L.C., J. CARNEIRO AND R. KELLEY 1995. Basic Histology, 8thEd, Lange Medical Book; pp.1-2.

LAI, P.K., AND J. ROY. 2004. Antimicrobial and chemopreventive properties of herbs and spices. Current medicinal chemistry, 11(11): 1451-1460.

LARSON, A.M., J. POLSON, R.J. FONTANA, T.J. DAVERN, E. LALANI, L.S. HYNAN, AND W.M. LEE. 2005. Acetaminophen-induced acute liver failure: results of a United States multicenter, prospective study. Hepatology, 42(6): 1364-1372

MAITI R., D. JANA, U.K. DAS, AND D. GHOSH. 2004. Antidiabetic effect of aqueous extract of seed of Tamarindus indica in streptozotocin-induced diab-etic rats. J Ethnopharmacol, 92: 85-91.

MCGILL, M.R., C.D. WILLIAMS, Y. XIE, A. RAMACHANDRAN, AND H. JAESCHKE. 2012. Acetaminophen-induced liver injury in rats and mice: comparison of protein adducts, mitochondrial dysfunction, and oxidative stress in the mechanism of toxicity. Toxicology and applied pharmacology, 264(3): 387-394

MORE, D., V. SHETTY, A. SHAH, S. MUNGEKAR, S.K. KAMAT, AND N.N. REGE. 2008. Effects of polyherbal ayurvedic formulations on non-specific immunity: An experimental study. Indian J Pharmacol, 40, 2

MOSS, D.W., A.R. HENDERSON, AND J.F. KACHMAR. 1987. Enzymes. In: Tietz, NW, ed. Fundamentals of Clinical Chemistry, 3rd ed. Philadelphia: WB Saunders, 346-421.

MURIEL,P., T.GARCIAPIÑA, V. PEREZ-ALVAREZ, AND M. MOURELLE. 1992. Silymarin protects against paracetamol-induced lipid peroxidation and liver damage. Journal of Applied Toxicology, 12(6): 439-442.

NASSINI, R., S. MATERAZZI, E. ANDRÈ, L. SARTIANI, G. ALDINI, M. TREVISANI, AND E. CERBAI. 2010. Acetaminophen, via its reactive metabolite N-acetyl-p-benzo-quinoneimine and transient receptor potential ankyrin-1 stimulation, causes neurogenic inflammation in the airways and other tissues in rodents. The FASEB Journal, 24(12): 4904-4916.

NIMILA, C., R. KANAGASABAI, AND K.G. LALITHA. 2017. Hepatoprotective and Antioxidant Activity of Mollugo Nudicaulis against Paracetamol 
Induced Hepatotoxicity in Rats. International Journal of Pharmaceutical and Phytopharm acological Research, 3(6): 478-482

PARMAR, S.R., P.H. VASHRAMBHAI, AND K. KALIA. 2010. Hepatoprotective activity of some plants extract against paracetamol induced hepatotoxicity in rats. J Herbal Med Toxicol, 4(2): 101106.

REID, A.B., R.C. KURTEN, S.S. MCCULLOUGH, R. W. BROCK, AND J.A. HINSON. 2005. Mechanisms of acetaminophen-induced hepatotoxicity: role of oxidative stress and mitochondrial permeability transition in freshly isolated mouse hepatocytes. Journal of Pharmacology and Experimental Therapeutics, 312(2), 509-516

REITMAN, S., AND S. FRANKEL. 1957. A color-imetric method for the determination of serum glutamic oxalacetic and glutamic pyruvic transam-inases. American Journal of Clinical Pathology, 28: 56-63.

RICE-EVANS, C., N. MILLER, AND G. PAGANGA. 1997. Antioxidant properties of phenolic compounds. Trends in plant science, 2(4), 152-159.

ROSEN H.R., H.R. KEEFFE. 2000. Evaluation of abnormal liver enzymes, use of liver test and the serology of viral hepatitis, In: Bacon BR, Bisceglie AM. Liver Disease Diagnosis and management, New York, Churchill Livingstone., pp. 24-35.

SHAKER, E., H. MAHMOUD, AND S. MNAA. 2010. Silymarin, the antioxidant component and Silybum marianum extracts prevent liver damage. Food and Chemical Toxicology, 48(3): 803-806

SZASZ, G. 1969. A kinetic photometric method for serum glutamyle-transpeptidase. Clinical Chemistry, 15:124-136.

TIETZ, N.W. 1986. Textbook of Clinical Chemistry, W.B. Saunders.

WALUBO, A., S. BARR, A.M. ABRAHAM, AND C. COETSEE. 2004. The role of cytochrome-P450 inhibitors in the prevention of hepatotoxicity after paracetamol overdose in rats. Human and experimental toxicology, 23(1): 49-54.

ZIMMERMAN H.J., K.G. ISHAK, R. MACSWEEN, P.P. ANTHONY, P.J. SCHEUER, A.D. BURT, ET AL. Edinburgh: Churchill Livingstone; 1994. Hepatic injury due to drugs and toxins, in Pathology of Liver; pp. 563-634.

\title{
تأثيرات الممكنه لحماية الكبد بمستخلص بذور الخردل ضد الاصابة الكبديه التي يسببها الباراسيتامول في الأكور فئران البيضاء ألاهية
}

\author{
هويده السيد خالد \\ قسم علم الحيوان، كلية العلوم، جامعة السويس، السويس، مصر الئر \\ الملخص العربي
}

تم تقييم التاثير الكبدي لمستخلص بذور الخردل (MS) عن طريق تقيم الحيو انات الي ع مجموعات، كل مجموعة مكونة من ه فئر ان. المجمو عة الاولي تعمل كمجمو عة ظابطه. المجموعة الثانية معالجة بالمستخلص الايثانولي لبذور الخردل . . م مغ/كغ لمدة • ا ايام. المجمو عة الثالثة تمثل الحيوانات التي تم عمل اصنابة كبديه لها بواسطة جر عه واحده من ال PCT. المجمو عه الرابعة AST, ALT, ALP, GGT and LDH المثل الفئران ذات الاصابة الكبدية و معالجة بمستخلص بذور الخردل. الانزيمات مثل في المجموعة الثالثة تبين انها مرتفعة مقارنة بالمجموعات الظابطه. وقد لوحظ ان مستوى هذه الانزيمات قد ابدي تحسن ملحوظ في المجمو عه التي تم معالجتها بمستخلص بذور الخردل مع PCT; (المجموعة الرابعة). كما لوحظ ان التغيرات الهستوباثولوجيه المحدثه في الفئر ان المعالجه بال PCT كانتفاخ الخلايا،اتساع الجيوب الكبديه،و التهاب الخلايا الكبديه، وزيادة حجم خلايا كوفر قد اظهرت حدة اقل في المجموعة الي تم معالجتها ببذور الخردل ولكن لم تعود الخلايا الي شكلها الطبيعي. وبالتالي نستنتج ان بذور

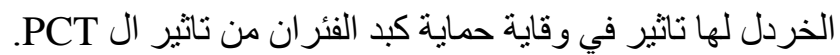

